\title{
Commentary
}

\section{HPV infection: in need of timely intervention}

\author{
Ankit Chaudhary ${ }^{1}$, Vijay K. Barwal ${ }^{1 *}$, Shaina Chamotra ${ }^{2}$, Anjali Mahajan ${ }^{1}$ \\ ${ }^{1}$ Department of Community Medicine, ${ }^{2}$ Department of Obstetrics and Gynaecology, Indira Gandhi Medical College
} Shimla, Himachal Pradesh, India

Received: 01 September 2018

Accepted: 01 October 2018

*Correspondence:

Dr. Vijay K. Barwal,

E-mail: barwalvk@gmail.com

Copyright: $\odot$ the author(s), publisher and licensee Medip Academy. This is an open-access article distributed under the terms of the Creative Commons Attribution Non-Commercial License, which permits unrestricted non-commercial use, distribution, and reproduction in any medium, provided the original work is properly cited.

\section{ABSTRACT}

Persistent infection with human papilloma virus (HPV) has been proved beyond doubt to be associated with the development of cervical cancer. One woman dies of cervical cancer every 8 minutes in India. As per estimations for the year 2018, about 96922 new cervical cancer cases are diagnosed annually in India and it ranks as the second most common female cancer in all age groups. But being an infectious cause it is possible to contain its development and transmission. Coupled with this, we have a potent vaccine to fight this infection. A well documented account of positive impact of HPV vaccination has been published in numerous studies around the globe. By 2013, its vaccination had been introduced in about fifty countries around the globe. In India also, recently, two HPV vaccination projects for operational feasibility were launched in Andhra Pradesh and Gujarat. In November 2016, Punjab became the first state in the country to include the vaccine in its universal immunization program. This era belongs to women empowerment and we cannot deny them the opportunity of good health. Hence it's high time India introduces an effective HPV vaccination program.

Keywords: HPV infection, Cervical cancer, HPV vaccine

\section{INTRODUCTION}

Human papilloma virus (HPV) is a sexually transmitted virus and its association with chronic diseases has been well documented. ${ }^{1}$ Although majority of its infections are benign and transient, but persistent infection with HPV is associated with development of cervical cancer. Moreover there is growing evidence of HPV being a relevant factor in other anogenital cancers like anus, vulva, vagina and penis, as well as head and neck cancers. ${ }^{2}$ Its association with cervical cancer in particular has been proved scientifically beyond any reasonable doubt.

\section{BURDEN}

All sexually active women are infected with HPV at least once during their lifetime, and the highest prevalence is seen soon after the onset of sexual activities. ${ }^{3}$ Worldwide
HPV is associated with 50,000 new cases of cervical cancer and 250,000 associated cervical cancer deaths each year. ${ }^{4}$ Globally, HPV-16 and 18, the two vaccinepreventable types contribute to over $70 \%$ of all cervical cancer cases and after HPV-16/18, the six most common HPV types are the same in all world regions, namely 31 , $33,35,45,52$ and 58; these account for an additional $20 \%$ of cervical cancers worldwide. World over about 569847 new cervical cancer cases are diagnosed annually and cervical cancer is the second most common female cancer in women aged 15 to 44 years. ${ }^{5}$ One woman dies of cervical cancer every 8 minutes in India. As per estimations for the year 2018, about 96922 new cervical cancer cases are diagnosed annually in India and here also it ranks as the second most common female cancer in all age groups. ${ }^{6}$ In the state of Himachal Pradesh, cancer cervix is a major public health problem since it ranked as the number one female cancer as per the annual reports of Regional Cancer Centre, Himachal Pradesh from 1998 to 
2008, with around 250 cases being registered annually. ${ }^{7}$ Therefore all these data suggest that it is a global burden affecting every demographic region.

\section{VACCINE RATIONALE}

In brief HPV infection has a high burden on our society in terms of mortality and morbidity. Though chronic and cancerous diseases have multifactorial causation, and also numerous risk factors are known to be associated with cervical cancer etiology, HPV infection has emerged as the single most important causal factor. But being an infectious cause it is possible to contain its development and transmission. ${ }^{8}$ Coupled with this, we have a potent vaccine to fight this infection.

\section{GLOBAL VACCINE STATUS}

Similar to many infectious diseases effective vaccines are available for the control of this disease. In 2006, the FDA approved the first preventive HPV vaccine, marketed by Merck \& Co. under the trade name Gardasil, a quadrivalent vaccine. ${ }^{9}$ Cervarix, a bivalent vaccine marketed by GlaxoSmithKline was approved for use in the U.S. in October 2009. ${ }^{10}$ In December 2014, US FDA approved Gardasil 9 which is protective against nine serotypes. $^{11}$ In April 2007, Australia became the first country to introduce a Government-funded National HPV Vaccination Program. ${ }^{12}$ By 2013, HPV vaccination has been introduced in about fifty countries around the globe with UK, USA, Australia, France, Germany, Italy, Japan, Norway, Sweden, Switzerland to name a few. ${ }^{13}$

\section{VACCINE EFFICACY}

A comparative study on HPV-type prevalence in Pap smears in Australian women aged 18-24 years in the prevaccination period (2005-2007) and in the postvaccination period (2010-2011) using the same recruitment and testing strategies showed that the prevalence of vaccine HPV genotypes was significantly lower in the postvaccine sample than in the prevaccine sample (6.7 versus $28.7 \%$; $\mathrm{p}<0.001) .{ }^{14}$ In USA, between the prevaccine and vaccine eras, HPV type prevalence declined from $11.5 \%$ to $4.3 \%$ among females aged 14 to 19 years and from $18.5 \%$ to $12.1 \%$ among females aged 20 to 24 years. ${ }^{15}$ Similarly global studies like PATRICIA trial and the FUTURE trial have equally proven vaccine efficacy. ${ }^{16,17}$ A well-documented account of positive impact of HPV vaccination has been published in numerous studies around the globe.

\section{NATIONAL SCENARIO}

As the data has been quoted earlier, India is not behind than rest of world in acquiring HPV infection and its chronic long term consequences. Recently, two HPV vaccination projects for operational feasibility were launched in Andhra Pradesh and Gujarat. However, the programs ran into controversy after alleged four deaths and complications among 120 girls were reported after vaccination and the program was terminated. ${ }^{18}$

Apart from these controversies, a few other challenges are also there regarding implementation of vaccination program with the cost being the major obstacle. Speaking in monetary terms, bivalent vaccine costs around Rs. 3300 per dose while single dose of quadrivalent vaccine costs around Rs.2800. ${ }^{19}$ With multiple doses of both vaccines recommended in schedule the expense reaches even higher.

Furthermore in November 2016 Punjab became the first state in the country to include HPV vaccination in its universal immunization program with the assistance of World Health Organization country office for India. HPV vaccine has been rolled out in two districts and will subsequently be expanded to rest of the state. In phase one, close to 10000 girls studying in class six of government schools were covered reflecting a $95 \%$ mobilization which shows enormous commitment. ${ }^{20}$

\section{RECOMMENDATIONS}

Our country cannot sit back and let the limitations overpower the countermeasures. Controversies should not hinder the development of a well needed nationwide vaccination program. With better vaccines and safety trials the program should be reinitiated. And cost should not halt the development of this future as we are dealing in health and lives rather than going for earning profits. Strategies should be developed for bringing the cost down, like manufacturing of multi dose vials for mass vaccinations. Also Indian manufacturers can be encouraged to manufacture the vaccine and bulk purchases can be made from foreign suppliers. Assistance from agencies such as WHO can be sought like the help taken by the state of Punjab. Single dose vaccination can be implemented as it has been done countries like Costa Rica and found to be effective. ${ }^{21}$

\section{CONCLUSION}

It's high time for India to launch an effective HPV vaccination program. A few hiccups here and there cannot halt the progress in this case. This era belongs to women empowerment and we cannot deny them the opportunity of good health. Simple and timely intervention like vaccination can save them from long term consequences and ensure the less expenditure on diagnostics and treatment in future. In nutshell, HPV related diseases are preventable and these should indeed be prevented.

\section{Funding: No funding sources Conflict of interest: None declared \\ Ethical approval: Not required}




\section{REFERENCES}

1. Bauer HM, Ting Y, Greer CE, Chambers JC, Tashiro CJ, Chimera J, et al. Genital human papillomavirus infection in female university students as determined by a PCR-based method. JAMA. 1991;265:472-7.

2. Bruni L, Barrionuevo-Rosas L, Albero G, Serrano B, Mena M, Gómez D, et al. ICO/IARC Information Centre on HPV and Cancer (HPV Information Centre). Human Papillomavirus and Related Diseases in India. Summary Report 27 July 2017. Available at: http://www.hpvcentre.net/statistics/ reports/IND.pdf. Accessed on 03 December 2018.

3. Brown DR, Shew ML, Qadari B, Neptune N, Vargas M, Tu W, et al. A longitudinal study of genital papiloma virus infection in a cohort of closely followed adolescent women. J Infect Dis. 2006;191:182-92.

4. Moscicki AB. Impact of HPV infection in adolescent populations. J Adolesc Health. 2005;37(6):3-9.

5. International agency for research on cancer. World Health Organization. Cancer today. Available from: https://gco.iarc.fr/today/data/factsheets/cancers/23Cervix-Uteri-fact-sheet.pdf. Accessed on 12 November 2018.

6. India against cancer. National Institute of cancer Prevention and research (NICPR). Globocan 2018: India Factsheet. Available at: http://cancerindia.org. in/globocan-2018-india-factsheet/. Accessed on 22 November 2018.

7. Himachal Pradesh: Regional Cancer Centre; 19982008: 116-418.

8. What Are the Risk Factors for Cervical Cancer? Available at: http://www.cancer.org/cancer /cervicalcancer/detailedguide/cervical-cancer-riskfactors. Accessed on 12 November 2018.

9. Merck Reports Double-Digit Earnings-Per-Share Growth for Second Quarter 2007.

10. "October 16, 2009 Approval Letter-Cervarix". U.S. Food and Drug Administration (FDA). 2009. Accessed on 10 November 2018.

11. "FDA approves Gardasil 9 for prevention of certain cancers caused by five additional types of HPV"(press release). 10 December 2014. Accessed on 11 October 2018.

12. Garland SM. The Australian experience with the human papillomavirus vaccine. Clin Ther. 2014;36(1):17-23.

13. Countries using HPV vaccination in national immunization schedule and planned introductions
2013. Available at: http://www.who.int/ immunization/diseases/hpv/decision_implementatio n/en/. Accessed on 04 November 2018.

14. Tabrizi, S, Brotherton J, Kaldor J, Skinner S, Cummins E, Liu B, et al. Fall in human papillomavirus prevalence following a national vaccination program. J Infect Dis; 2012;206:164551.

15. Markowitz LE, Liu G, Hariri S, Steinau M, Dunne EF, Unger ER. Prevalence of HPV After Introduction of the Vaccination Program in the United States Pediatrics. 2016;137(3).

16. Lehtinen M, Paavonen J, Wheeler CM, Jaisamrarn U, Garland SM, Castellsagué X, et al. HPV PATRICIA Study Group Overall efficacy of HPV16/18 AS04-adjuvanted vaccine against grade 3 or greater cervical intraepithelial neoplasia: 4-year end-of-study analysis of the randomised, doubleblind PATRICIA trial. Lancet Oncol. 2012;13(1):89-99.

17. Garland SM, Hernandez-Avila M, Wheeler CM, Perez G, Harper DM, Leodolter S, et al. Females United to Unilaterally Reduce Endo/Ectocervical Disease (FUTURE) I Investigators Quadrivalent vaccine against human papillomavirus to prevent anogenital diseases. New Engl J Med. 2007;356(19):1928-43.

18. Judges demand answers after children die in controversial cancer vaccine trial in India 2015 Available at: http://www.dailymail.co.uk/news/ article-2908963/Judges-demand-answers-childrendie-controversial-cancer-vaccine-trial-India.html. Accessed on 02 November 2018.

19. Your daughter needs to be vaccinated for cervical cancer. Here is why 2016. Available at: http://www.hindustantimes.com/india/is-hpvvaccine-safe-for-my-daughter-yes/story4gBa5z5rDtxREhNJ6lzzQP.html. Accessed on 05 November 2018.

20. Punjab launches HPV vaccine with WHO support 2016. Available at: http://www.searo.who.int/ india/mediacentre/events/2016/Punjab_HPV_vaccin e/en/. Accessed on 08 October 2018.

21. Kreimer AR, Struyf F, Del Rosario-Raymundo MR, Hildesheim A, Skinner SR, Wacholder S, et al. Efficacy of fewer than three doses of an HPV-16/18 AS04-adjuvanted vaccine: combined analysis of data from the Costa Rica Vaccine and PATRICIA trials. Lancet Oncol. 2015;16:775-86.

Cite this article as: Chaudhary A, Barwal VK, Chamotra S, Mahajan A. HPV infection: in need of timely intervention. Int J Sci Rep 2019;5(2):66-8. 